\title{
Changing Pattern of Land Use in the Calabar River Catchment, Southeastern Nigeria
}

\author{
Joel Efiong \\ Department of Geography and Regional Planning \\ University of Calabar, P. M. B. 1115, Calabar \\ Cross River State - Nigeria \\ Tel: 234-803-273-8080 E-mail: joel_efiong@yahoo.com
}

\begin{abstract}
Rapidly increasing human populations and expanding agricultural activities have brought about extensive land use changes throughout the world. Though human beings have been modifying land to obtain food, shelter and other essentials of life for thousands of years, current rates, extents and intensities of such modifications are far greater than ever in history and continue undocumented. This study examined the various land uses, the changes that have occurred and the rates of such changes in the Calabar river catchment between 1967 and 2008. Data for the study were obtained from both the topographic maps and satellite imagery. The following mosaic of land uses- built-up, plantation, fallow land/scattered cultivation, high forest, low forest mangrove, river and quarrywere identified. High forest was the most affected of the land uses, decreasing by 29.92 per cent at the rate of 0.73 per cent year ${ }^{-1}$ (or loss of $11045.51 \mathrm{~m}^{2} \mathrm{year}^{-1}$ ). The current pattern of change in the land use is not sustainable. Hence, reforestation has been recommended, particularly in the lower segment of the catchment to enhance sustainability.
\end{abstract}

Keywords: Land use, Change, Calabar river, Catchment, Human activities

\section{Introduction}

The land use pattern of a region is an outcome of natural and socio -economic factors and their utilization by man in time and space. Land is becoming a scarce resource due to immense agricultural and demographic pressures. Cunningham, Cunningham and Siago (2005) have noted that rapidly increasing human populations and expanding agricultural activities have brought about extensive land use changes throughout the world. Hence, information on land use and possibilities for their optimal use is essential for the selection, planning and implementation of land use schemes to meet the increasing demands for basic human needs and welfare. This information also assists in monitoring the dynamics of land use resulting out of changing demands of increasing population.

Though human beings have been modifying land to obtain food, shelter and other essentials of life for thousands of years, current rates, extents and intensities of such modifications are far greater than ever in history and continue undocumented. This has driven unprecedented changes in ecosystems and environmental processes at local and regional scales. Monitoring and mediating the negative consequences of land use changes while sustaining the production of essential resources has therefore become a major priority of researchers and policymakers around the world.

There is no gain saying the fact that there has been a worldwide increasing awareness and studies on land use change analysis in the last four to five decades, particularly in the tropics. The importance of such studies to sustainable development plans of nations has also been universally recognized. However, Okude (2006) noted that there is still an extremely low level of recognition and research attention on land use change studies in Nigeria.

In Calabar (the Cross River State Capital), current land development has shifted towards the northern part of the city as further development towards the west, east and south have been restricted by the Calabar river, Great Kwa river and the wetlands of the Cross river estuary, accordingly. For example, the National Integrated Power Project is making use of a large expanse of land at Ikot Nyong in Odukpani Local Government Area and is situated along the Calabar- Itu highway. Other residential developments and human activities have affected the land use/cover in the Calabar river catchment. Yet there is little or no empirical information on the pattern of land uses and their rates of change in this catchment.

According to Ayoade (1988), substantial changes in vegetation and rural land use have taken place in the tropics since the beginning of the last century. Unfortunately, land use changes by deforestation have not been given attention as an important environmental change in the same way as urbanisation. This is a dangerous oversight 
particularly in the Calabar river basin as what happens in the upstream section would directly or indirectly affect Calabar which is not just the State Capital of Cross River State, but also the home of the Africa's Premier Business and Leisure Resort: The Tinapa. The original vegetation of the entire Calabar river watershed was the tropical rainforest. However, most of these original vegetation in the study area has been replaced as a result of agricultural, road construction, tree logging and exploitation (Table 1), industrial and residential activities. This has resulted in a mosaic of land uses in the catchment.

Monitoring the consequence of land use change in the area is met with the non-availability of empirical data. Hence, this study identifies the various land uses, examines the changes that have occurred among them and the rates of such changes in the Calabar river catchment of southeastern Nigeria. The result of this work would provide empirical data, which, when properly utilised will contribute to the sustainable management of the catchment. This will ensure the meeting of human needs in the present, while preserving the environment so that the needs of the future generations could also be met.

\section{Review of Related Literature}

\subsection{The Concept of Land Use}

According to Clawson and Stewart (1965), land use refers to, "mans activities on land which are directly related to the land." It describes how a portion of the earth's surface is used by man (such as for industry, habitation, agriculture, etc). But Efiong-Fuller (2008) defines land use in terms of syndromes of human activities such as agriculture, forestry and building construction that alter land surface processes including biogeochemistry, hydrology and biodiversity.

However, there is no ideal classification system of land use, and it is unlikely that one could ever be developed (Anderson, Hardy, Roach \& Witner, 1976; Efiong-Fuller, 2008). This is because there are many perspectives in the process of classification. Again, each classification is made to suit specific user needs which thereby impose a number of criteria in deciding the land use classes. It should be borne in mind that land use is dynamic and their patterns change over time in response to human demands for natural resources. A particular land use classification scheme may therefore not be adequate.

Essentially, classification is a semantic process, providing the means of distinguishing between information, and thereby enabling access to it for particular purposes (Efiong-Fuller, 2008). Often, classification is performed in such a way that categories are grouped into successively higher levels that enables phenomena to be referred to at different levels of abstraction.

\subsection{The Concept of Change Detection}

The environment is progressively dynamic which is in response to the use man puts it and management practices. Therefore, when the environment reacts, it is simply readjusting to the changes which either sustains or degrades it. Change detection according to Singh (1989) and Mejabi (2008) is the concept of identifying contrasts or discrepancies in the state of an object or phenomenon by observing it at different times. This involves the ability to quantify temporal alteration and transformation using multi-temporal data sets. In general, change detection involves the application of multi-temporal data sets to quantitatively analyse the temporal effects of the phenomenon. According to Green, Kemkpa and Lackey (1994), the objective of change detection is to compare spatial representation of two points in time by controlling all variances that are not of interest and to measure changes caused by differences in the variables of interest.

Mejabi (2008) noted that change detection studies recognise the biotic and abiotic components of multi-spectral and multi-temporal variations that are occurring within an ecosystem. These studies are based on two types of techniques:

1) Map-to-map comparison: This relies on the identification of the differences between two or more maps of different data set of the same location

2) Image-to-image comparison: This relies on the identification of two or more imageries of different data sets of the same location.

Many change detection techniques have been developed. For the sake of convenience, Lu, Mausel, Brondizio and Moran (2004) grouped change detection methods into seven categories: (1) algebra, (2) transformation, (3) classification, (4) advanced models, (5) Geographical Information System (GIS) approaches, (6) visual analysis, and (7) other approaches. The main characteristics, advantages and disadvantages, key factors affecting change detection results and some application examples have been provided in their work for the first six categories. The seventh category includes those change detection methods that are not suitable to be grouped into any one of the 
six categories and are not yet used extensively in practice.

Although a large number of change detection applications have been implemented and different change detection techniques have been tested, conclusion on which method that is best suitable for specific study area remains unanswered. For the present study, the visual analysis based on the map-to- map comparison techniques was adopted. Han, $\mathrm{Li}$ and $\mathrm{Gu}(2008)$ has noted that conventional map-to-map comparison method is used frequently for land use change detection.

The visual analysis category includes visual interpretation of multi-temporal image composite and on-screen digitizing of changed areas (Lu et. al., 2004). Practically, it involves the visual interpretation of the colour composite to identify changed areas or implementing an on-screen digitizing of changed areas using visual interpretation based on overlaid images of different dates. This method makes use of the analyst experience and knowledge. Loveland et. al. (2002) used visual interpretation of fine resolution data combined with sampling design to detect United States land cover changes and estimate change rates. This method has also been adopted by Sunar (1998), Ulbricht and Heckendorff (1998), Sadar and Winne (1992), Stone and Lefebvre (1998), Asner, Keller, Pereira and Zweede (2002) and Slater and Brown (2000), among others.

\subsection{Empirical Case Studies from Nigeria}

Ademiluyi, Okude and Akanni (2008) reviewed some of the foremost works in this area from Nigeria which included NIRAD Project (1976/79), Areola (1977), FORMECU (1996) and Omojola (1997). While the NIRAD Project, Areola's work and FORMECU Project were more of land use classification, Omojola extended his work to cover change detection.

Ekpenyong (2008) used the GIS database to model the land use/cover change between 1984 and 2003 for Akwa Ibom State. The result showed that some urban centres had expanded into farmlands/fallow lands and the surrounding secondary forest. Within that period, mangrove forest had reduced by 50 per cent. Other forest covers in the area also changed, threatening food security and climate among others.

While examining the process of land use conversion and rate in common and public lands in South-Eastern Nigeria between 1972 and 2001, Bisong (2007) showed that deforestation was higher in publicly controlled lands than in communal lands. Agricultural land use characteristics, such as farm types and the nature of croplands/fallows, correlated strongly and significantly with deforestation rates. Similarly, Idoko, Bisong, Bisong and Okon (2008) analyzed satellite imageries of 1987 and 2004 for the Federal Capital Territory, Abuja for land use change. The imageries were characterized into five classes using maximum likelihood algorithm. The classes were vegetation, built-up, rock outcrop, water body and farm land. The two classified imageries were compared to identify any changes. Also, a spatio-temporal change in land use type was obtained in quantitative terms. The analysis revealed that vegetation cover reduced by 85.22 per cent between 1987 and 2004. Again, the built-up area increased by 21.99 per cent and farm land increased by 0.14 per cent.

In their study on participatory land use planning for community based forest management in south-eastern Nigeria, Bisong, Animashaun and Andrew-Essien (2007) presented an empirical classification of current land uses in their study area. They include those under high forest, secondary forest, savanna/grasslands, swamplands and farm/fallow lands. About 51 per cent of the overall land uses was classified under tropical high forest from a total land area of $665.72 \mathrm{~km}^{2}$. The values ranged between 38 per cent in Agoi-Ekpo community to 91 per cent in Etara/Ekuri-Eyeyeng Communities. They concluded that high forest was the dominant land use type followed by secondary forest and farm/fallow lands in all the three communities studied.

\section{Study Area}

The Calabar river catchment is located in the southeastern part of Nigeria and precisely in Cross River State (Figure 1). Based on Köppen's climatic classification, the area falls within the tropical rainforest climate. The original vegetation of the entire Calabar river catchment was the tropical rainforest. However, most of the original vegetation in the study area has been replaced as a result of agricultural, road construction, tree logging, industrial and residential activities. Though, the catchment can still be classified under the tropical rainforest, it is only in a few places that the structural organisation can be clearly distinguished.

\section{Method of Study}

The topographic map of the study area was scanned into the computer and transferred onto the GIS environment. The map was then geo-referenced and different land use features noted and demarcated. Different land use classes were obtained and their different thematic maps produced using the Integrated Land and Water Information System (ILWIS) version 3.2 software developed by the International Institutes for Aerospace Survey and Earth Sciences, Netherlands (1997). 
Satellite imagery of 2008 for the study area was downloaded from the Google Earth in the internet using the Google Earth Pro software. The interpretation of the image was done visually. The elements of visual image interpretation as noted by Jenson (2007) used in the visual analysis were tone and colour. This was possible as the imagery gave the true colour reflection of images on ground. Tone has been described as shades of gray, ranging from black to white.

The degree of darkness or brightness is a function of the amount of light reflected from the scene within the specific wavelength interval or band (Jenson, 2007). Very dark-green colours were interpreted as forest with no observed human impact. These were regarded as the high forests. Lighter green colours were interpreted as areas with little human activities. Lighter colours with well- defined outline were interpreted as plantations. Very light green colours were interpreted as fallow lands or scattered cultivations. The white patches on the imagery were interpreted as areas with intensified human activities. These were considered as residential areas. During ground truthing, some of these areas were later identified as quarry sites.

The geo-database for the final production of the land use maps was designed on the computer using the ArcMap 9.0 GIS software. The different land uses were organized in thematic layers using the ArcMap 9.0, but presented as one in the final analysis. Arctur and Zeiler (2004) have provided the full details for designing geo-databases for interested readers.

Land use classes such as built-up, high forest, low forest, mangrove, plantation, fallow land/ scattered cultivation, etc were noted on both the 1967 and 2008 land use maps. Another fieldwork was embarked upon to ascertain the land uses obtained from topographical maps and satellite imageries. Areas (in $\mathrm{m}^{2}$ ) of the various land use classes were calculated using the square method (Ajaegbu \& Faniran, 1992). Areas (in percentages) of each of the land use classes with respect to the total of the basin were determined for the two land use maps. The change in land use was obtained as the difference in areal $\left(\mathrm{m}^{2}\right)$ calculation between 1967 and 2008 land use maps for each of the land use classes. Similarly, the percentage change in land use was calculated as the difference between the percentage of the land use types in 1967 and 2008.

Finally, the average rates of change for the different classes of land uses were obtained by dividing the percentage change in areal coverage of the land use by the number of years taken for the change to occur. In this particular case, the number of years taken for the change to occur is $2008-1967$ which equals 41 years.

\section{Results}

Mosaics of land uses in 1967 and 2008 are presented in figures 2 and 3 respectively. Major land uses in figure 2 include high forest, low forest, fallow land/scattered cultivation, plantation, mangrove and built-up areas. Figure 3 which present the land use map of the basin in 2008 shows that a lot of changes have taken place. There is also an additional land use class (quarry) in the 2008 land use map. Hence, the catchment as at 2008 is characterized by at least seven (7) major mosaics of land uses. Table 2 shows the land use mosaics of the Calabar river catchment as they were in 1967 and 2008. Table 3 presents the rate of land use change.

\section{Discussion of Findings}

From the change detection analysis of the 1967 and 2008 land use maps of the Calabar river basin, a drastic change in land use has been observed (Figure 4). The most affected of all the land uses was the high forest which reduced from 69.39 per cent of the total basin area in 1967 to 39.47 per cent in 2008 . The rate of reduction here has been noted to be higher than any other land use type within the basin (Table 3). The rate of this negative change has been determined as 0.730 per cent year ${ }^{-1}$. If current rate of reduction in the high forest area is allowed to continue, there may be no high forest again in the area in the next 50 years, jeopardizing the need of the future generation and causing greater harm to the environment.

Forest removal has been observed as one of the key factors enhancing global warming that is threatening the environment. Plants make use of carbon dioxide (a greenhouse gas) during photosynthesis thereby reducing its concentration in the atmosphere. Hence, forest removal should be discouraged as much as it is possible. Whereas the high forest experienced a reduction in size between 1967 and 2008, the reverse was the case for low forest. This should be the case as most of the conversions of high forest to other land uses are not usually directly. The state of low forest is necessary, hence it increase in size.

Other land uses were also discovered to have changed though not necessarily at very high rates. Noticeably, quarrying has also become a dynamic factor of land use change in the area. This was noticed in the land use map of 2008. This particular land use type was not present in 1967 as industrial quarrying activities in the area began in the 1980s. This could also have much effect on the water discharge by the river and could particularly caused stream siltation and flooding aside air and water pollution. 
Also, it was discovered that about 53 per cent of the people in the study area were involved in farming (Table 5). Farming is one of the human activities that have been noted to be accompanied by drastic change in land cover. Equally, about 14 per cent of the people were discovered to be involved in activities other than farming, civil service jobs and trading. Such activities which included logging of woods and hunting are also the likely cause of land use change in the area.

\section{Conclusion}

Studies on land use have revealed that significant changes have taken place over the last two to three decades, particularly in the tropics. The findings of the present study have supported that fact. Also, this study revealed a high rate of land use change in the Calabar river catchment. A major change was noted with respect to the change from forest to other land uses between 1967 and 2008. There is a high rate of change of high forest to other land uses. If such rate continues, there may be no high forest in the catchment in the next 50 years. This is against the concept of sustainable development and may trigger off other environmental problems like erosion, flooding and increase carbon dioxide in the atmosphere which could contribute to global warming. Hence, reforestation should commence in earnest, particularly in the lower part of the catchment. Also, the current ban on logging of wood from the forest in Cross River State by the state government should be enforced comprehensively for some time. This would reduce the rate of current tree removal and encourage sustainable development within the catchment.

\section{References}

Ademiluyi, I. A., Okude, A. S. \& Akanni, C. O. (2008). An appraisal of landuse and landcover mapping in Nigeria. African Journal of Agricultural Research, 3 (9), 581 - 586.

Ajaegbu, H. I. \& Faniran, A. (1992). A new approach to practical geography. Ibadan: Heinemann Educational Books, (Chapter 2).

Anderson, J. R., Hardy, E. E., Roach, J. T. \& Witner, R. E. (1976). A land use and land cover classification system for use with remote sensor data. Geological Survey Professional Paper 964, Washington. United States Government Printing Office.

Arctur, D. \& Zeiler, M. (2004). Designing geodatabases: case studies in GIS data modelling. California: ESRI Press, (Chapter 1).

Areola, O. (1977). Aerial photo-interpretation of land types and terrain conditions in the Lagos coastal region, Nigeria. Geographical Journal, 20 (1), 70-84.

Asner, G. P., Keller, M., Pereira, R. \& Zweede, J. C. (2002). Remote sensing of selective logging in Amazonia assessing limitations based on detected field observations, landsat ETM + and textural analysis. Remote Sensing of the Environment, 80, 483-496.

Ayoade, J. O. (1988). Tropical hydrology and water resources. London: Macmillan, (Chapter 5).

Bisong, F. E. (2007). Land use and deforestation in the rainforest of South-eastern Nigeria (1972-2001). Nigerian Geographical Journal, 5 (1), 19 - 28.

Bisong, F. E., Animashaun, A. \& Andrew-Essien, E. (2007). Participatory land use planning for community based forest management in South-eastern Nigeria. LWATI: A Journal of Contemporary Research. 4, 329 - 347.

Cross River State Forestry Commission (1988, 1990, 2000, 2001 and 2003). Annual report. Calabar: Forestry Commission.

Cunningham, W. P., Cunningham, M. A., \& Siago, B. (2005). Environmental science: a global concern. New York: McGraw - Hill, (Chapter 12).

Efiong-Fuller, E. O. (2008). Land use mapping: a system approach. Unpublished lecture note, University of Calabar, p. 8-9.

Ekpenyong, R. E. (2008). Analysis of findings from the Akwa Ibom State land use/land cover change early warning system. Nigerian Journal of Geography and the Environment, 1, 68 - 76.

Eze, E. B \& Efiong, J. (2010). Morphometric parameters of the Calabar river basin: implication for hydrologic processes. Journal of Geography and Geology, 2 (1), 18-26.

FORMECU. (1996). Preliminary report on the assessment of land use and vegetation changes in Nigeria between 1978 - 1993/95. Submitted by Geometrics International Inc., Ontario, Canada.

Green, K., Kemkpa, D. \& Lackey, L. (1994). Using remote sensing to detect and monitor land - cover and land 
-use change. Photogrammetric engineering and remote sensing, 60, 331 - 337.

Hans, S. S., Li, H. T. \& Gu, H. Y. (2008). The study of land use change detection based on object oriented analysis. International workshop on earth observation and remote sensing application EORSA 2008. 1 - 6.

Idoko, M. A., Bisong, F. E., Bisong, J. N. \& Okon, I. E. (2008). Application of geo-information for evaluation of land use change: a case study of Federal Capital Territory, Abuja. In Bisong, F. E. (Ed.), Geography and the millennium development goals: translating vision into reality (444-448). Calabar: Index Books Publishers.

Jenson, J. R. (2007). Remote sensing of the environment. (Second edition). Upper Saddle River: Pearson Prentice Hall, (Chapter 11).

Loveland, T. R., Sohi, T. L., Slehman, S. V., Gallant, A.L., Sayler, K. L. \& Napton, D. E. (2002). A strategy for estimating the rates of recent United States land-cover changes. Photogrammetric Engineering and Remote Sensing, 68, $1091-1099$.

Lu, D., Mausel, P., Brondizio, E. \& Moran, E. (2004). Change detection techniques. International Journal of Remote Sensing, 25 (12), 2365 - 2407.

Mejebi, D. J. J. (2008). An assessment of the various types of land degradation within the river Kubanni Basin of Zaria - Nigeria. In Bisong, F. E. (Ed.), Geography and the millennium development goals: translating vision into reality (64 - 70). Calabar: Ultimate Index Books publishers.

National Population Commission (2006). Nigeria’s Population Census 2006.

Okude, A. S. (2006). Landcover change along the Lagos coastal area. Ph.D Dissertation, Department of Geography, University of Ibadan, Nigeria, p. 93-95.

Omojola, A. (1997). Landuse and landcover inventory and change assesment in a semi-arid region in Nigeria using remote sensing and GIS Techniques. Ph.D Thesis, University of Lagos, Nigeria, p. 113-115.

Sadar, S. A. \& Winne, J. C. (1992). RGB-NDVI colour composites for visualizing forest change dynamics. International Journal of Remote Sensing, 13, 3055 - 3065.

Singh, A. (1989). Digital change detection techniques using remotely sensed data. International Journal of Remote Sensing, 10, 989 - 1003.

Slater, J. \& Brown, R. (2000). Changing landscapes: monitoring environmentally sensitive areas using satellite imagery. International Journal of Remote Sensing, 21, 2753 - 2767.

Stone, T. A. \& Letebvre. (1998). Using multitemporal satellite data to evaluate selective logging in Para, Brazil. International Journal of Remote Sensing, 19, 2517 - 2526.

Sunar, F. (1989). An analysis of change in multi-date data set: a case study in the Ikitelli Areas, Istanbul, Turkey. International Journal of Remote Sensing, 19, 225 - 235.

Ulbricht, K. A. \& Heckendorff, W. D. (1998). Satellite images for recognition of landscape and land use changes. Journal of Photogrammetry and Remote Sensing, 53, 235 - 243.

Table 1. Tree exploitation from forest reserves that traverse the Calabar river catchment

\begin{tabular}{|l|l|l|l|l|l|}
\hline \multirow{2}{*}{ Charge } & \multicolumn{5}{|c|}{ Number by Year } \\
\cline { 2 - 6 } & 1988 & 1990 & 2000 & 2001 & 2003 \\
\hline Awi-Akamkpa & 1176 & 159 & 1113 & 1375 & 667 \\
Oban & 295 & 1139 & 447 & 721 & 547 \\
Odukpani & 110 & 41 & 76 & 70 & 67 \\
\hline TOTAL & 1581 & 1339 & 1636 & 2166 & 1281 \\
\hline
\end{tabular}

Source: Cross River State Forestry Commission, Calabar (1988, 1990, 2000, 2001 and 2003) 
Table 2. Land use sizes for 1967 and 2008

\begin{tabular}{|c|c|c|c|c|}
\hline \multirow[t]{3}{*}{ Land use class } & \multicolumn{4}{|c|}{ Year } \\
\hline & \multicolumn{2}{|r|}{1967} & \multicolumn{2}{|c|}{2008} \\
\hline & Size (area, $\mathrm{m}^{2}$ ) & Percentage of total & Size (area, $\mathrm{m}^{2}$ ) & Percentage of total \\
\hline Built-up & 52990.00 & 3.50 & 115064.00 & 7.60 \\
\hline Plantation & 115972.40 & 7.66 & 92808.20 & 6.13 \\
\hline $\begin{array}{l}\text { Fallow land / } \\
\text { scattered } \\
\text { cultivation }\end{array}$ & 125813.40 & 8.31 & 269340.60 & 17.79 \\
\hline High forest & 1050564.60 & 69.39 & 597575.80 & 39.47 \\
\hline Low forest & 141104.80 & 9.32 & 411353.80 & 27.17 \\
\hline Mangrove & 9386.80 & 0.62 & 6056.00 & 0.40 \\
\hline River & 18168.00 & 1.20 & 16654.00 & 1.20 \\
\hline Quarry & 0.00 & 0.00 & 6510.20 & 0.43 \\
\hline Total & 1514000 & 100 & 1514000 & 100 \\
\hline
\end{tabular}

Source: Author's research (2009) 
Table 3. Rates of land use change

\begin{tabular}{|c|c|c|c|c|c|c|}
\hline \multirow[t]{2}{*}{$\begin{array}{l}\text { Land use } \\
\text { class }\end{array}$} & \multicolumn{2}{|c|}{$\begin{array}{c}\text { Percentages } \\
\text { according to year }\end{array}$} & \multirow[t]{2}{*}{$\begin{array}{c}\% \\
\text { change }\end{array}$} & \multirow[t]{2}{*}{$\begin{array}{l}\text { Areal change } \\
\left(\mathrm{m}^{2}\right)\end{array}$} & \multicolumn{2}{|c|}{ Rate of change } \\
\hline & 1967 & 2008 & & & Per cent year ${ }^{-1}$ & metres $^{2}$ year $^{-1}$ \\
\hline Built-up & 3.50 & 7.60 & +4.10 & +62074.00 & 0.10 & 1514.00 \\
\hline Plantation & 7.66 & 6.13 & -1.53 & -23164.20 & 0.04 & 564.98 \\
\hline $\begin{array}{l}\text { FallowLand } \\
\text { / Scattered } \\
\text { Cultivation }\end{array}$ & 8.31 & 17.79 & +9.48 & +143527.20 & 0.23 & 3500.66 \\
\hline High Forest & 69.39 & 39.47 & -29.92 & -452988.80 & 0.73 & 11048.51 \\
\hline Low Forest & 9.32 & 27.17 & +17.85 & +270249.00 & 0.44 & 6591.44 \\
\hline Mangrove & 0.62 & 0.40 & -0.22 & -3330.80 & 0.01 & 81.24 \\
\hline River & 1.20 & 1.10 & -0.10 & -1514.00 & 0.002 & 36.93 \\
\hline Quarry & $0.00^{*}$ & 0.80 & +0.80 & +6510.20 & $*$ & $*$ \\
\hline
\end{tabular}

* Quarry not in 1967 land use map

Source: Author's research (2009) 
Table 4. Occupation of residents of the area

\begin{tabular}{|c|c|c|c|c|c|c|c|c|c|c|c|}
\hline \multirow{2}{*}{$\begin{array}{l}\mathrm{S} / \\
\mathrm{N}\end{array}$} & \multirow{2}{*}{$\begin{array}{l}\text { Name of } \\
\text { village/tow } \\
n\end{array}$} & \multicolumn{2}{|c|}{ Farming } & \multicolumn{2}{|c|}{ Civil servant } & \multicolumn{2}{|c|}{ Trading } & \multicolumn{2}{|c|}{ Others } & \multicolumn{2}{|l|}{ Total } \\
\hline & & Freq. & $\begin{array}{l}\% \text { of } \\
\text { total }\end{array}$ & Freq. & $\begin{array}{l}\% \text { of } \\
\text { total }\end{array}$ & Freq. & $\begin{array}{l}\% \text { of } \\
\text { total }\end{array}$ & Freq & $\begin{array}{l}\% \text { of } \\
\text { total }\end{array}$ & Freq & $\begin{array}{c}\text { Total } \\
\%\end{array}$ \\
\hline 1. & $\begin{array}{l}\text { Odukpani } \\
\text { Qua Town }\end{array}$ & 40 & 50.63 & 27 & 34.18 & 12 & 15.19 & 0 & 0.00 & 79 & 100 \\
\hline 2. & $\begin{array}{ll}\text { Field } & 20 \\
\text { Camp } & \end{array}$ & 3 & 100.00 & 0 & 0.00 & 0 & 0.00 & 0 & 0.00 & 3 & 100 \\
\hline 3. & $\begin{array}{l}\text { (Pamol) } \\
\text { Camp B } \\
\text { (Pamol) }\end{array}$ & 3 & 100.00 & 0 & 0.00 & 0 & 0.00 & 0 & 0.00 & 3 & 100 \\
\hline 4. & Adiabo & 5 & 16.13 & 16 & 51.62 & 6 & 19.35 & 4 & 12.90 & 31 & 100 \\
\hline 5. & $\begin{array}{l}\text { Akai } \\
\text { Effiwatt }\end{array}$ & 3 & 100.00 & 0 & 0.00 & 0 & 0.00 & 0 & 0.00 & 3 & 100 \\
\hline 6. & Oduyama & 3 & 75.00 & 0 & 0.00 & 1 & 25.00 & 0 & 0.00 & 4 & 100 \\
\hline 7. & Ekenkpon & 9 & 42.86 & 3 & 14.29 & 3 & 14.49 & 6 & 28.56 & 21 & 100 \\
\hline 8. & Uwet & 24 & 80.00 & 3 & 10.00 & 3 & 10.00 & 0 & 0.00 & 30 & 100 \\
\hline 9. & Okom-Ita & 31 & 50.82 & 12 & 19.68 & 9 & 14.75 & 9 & 14.75 & 61 & 100 \\
\hline 10. & Uyanga & 58 & 58.00 & 21 & 21.00 & 11 & 11.00 & 10 & 10.00 & 100 & 100 \\
\hline 11. & Ikot Nyong & 5 & 71.42 & 1 & 14.29 & 1 & 14.29 & 0 & 0.00 & 7 & 100 \\
\hline 12. & Old Netim & 9 & 30.00 & 5 & 16.67 & 10 & 33.33 & 6 & 20.00 & 30 & 100 \\
\hline 13. & Igbofia & 2 & 66.67 & 1 & 33.33 & 0 & 0.00 & 0 & 0.00 & 3 & 100 \\
\hline 14. & Nyakasang & 10 & 62.50 & 2 & 12.50 & 3 & 18.75 & 1 & 6.25 & 16 & 100 \\
\hline \multicolumn{2}{|c|}{$\begin{array}{l}\text { Total } \\
\% \text { of total }\end{array}$} & $\begin{array}{c}205 \\
52.43\end{array}$ & & $\begin{array}{c}91 \\
23.27\end{array}$ & & $\begin{array}{c}59 \\
15.09\end{array}$ & & $\begin{array}{c}36 \\
9.21\end{array}$ & & $\begin{array}{l}391 \\
100\end{array}$ & \\
\hline
\end{tabular}

Source: Author's research, (2009) 


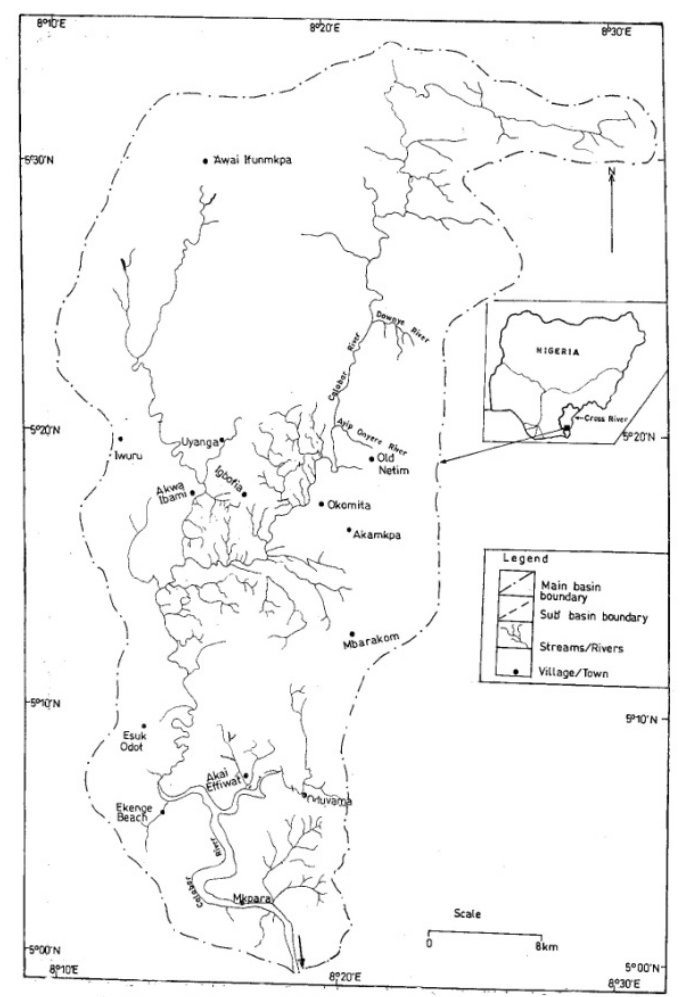

Figure 1. The Calabar river catchment (After Eze \& Efiong, 2010)

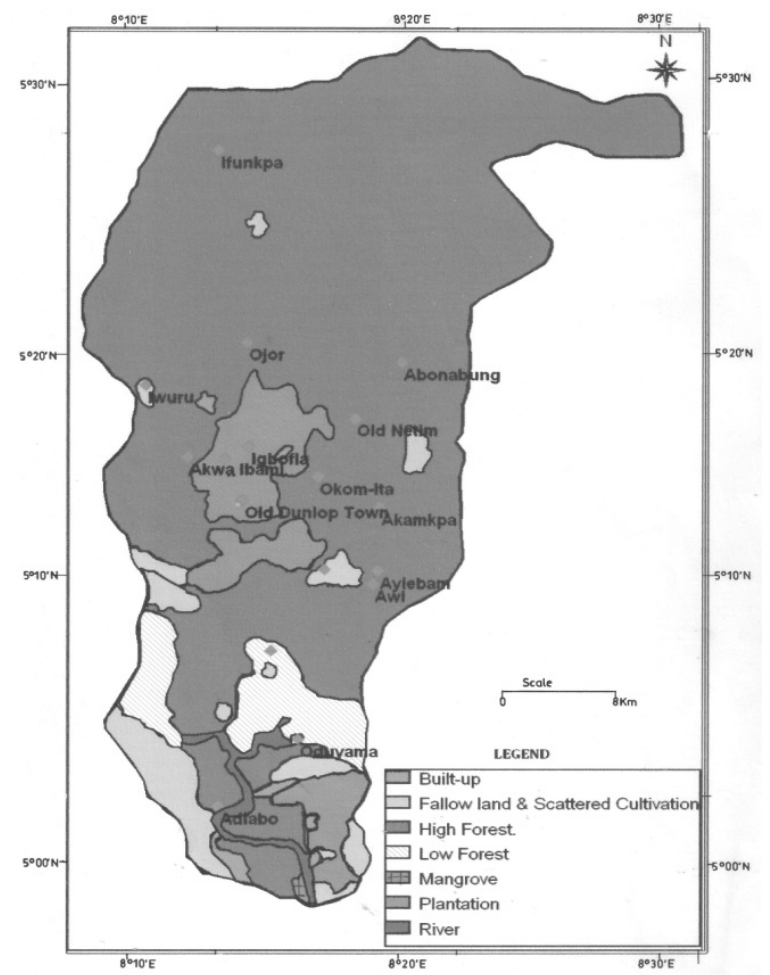

Figure 2. Land use map of Calabar river catchment for 1967 


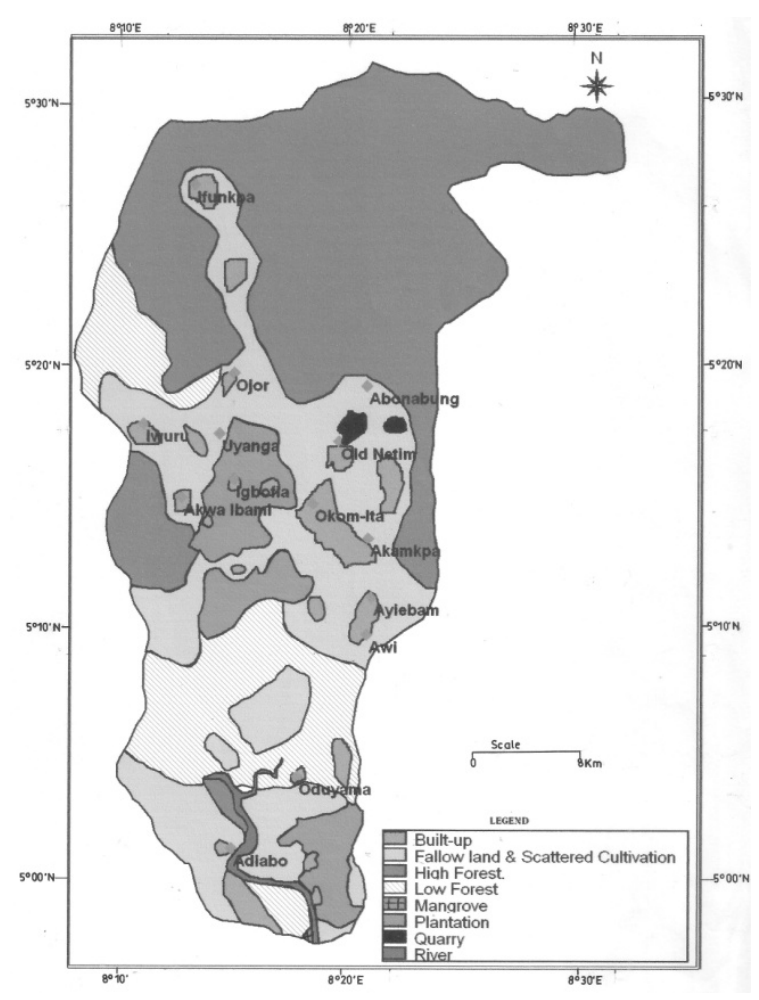

Figure 3. Land use map of the Calabar river catchment for 2008

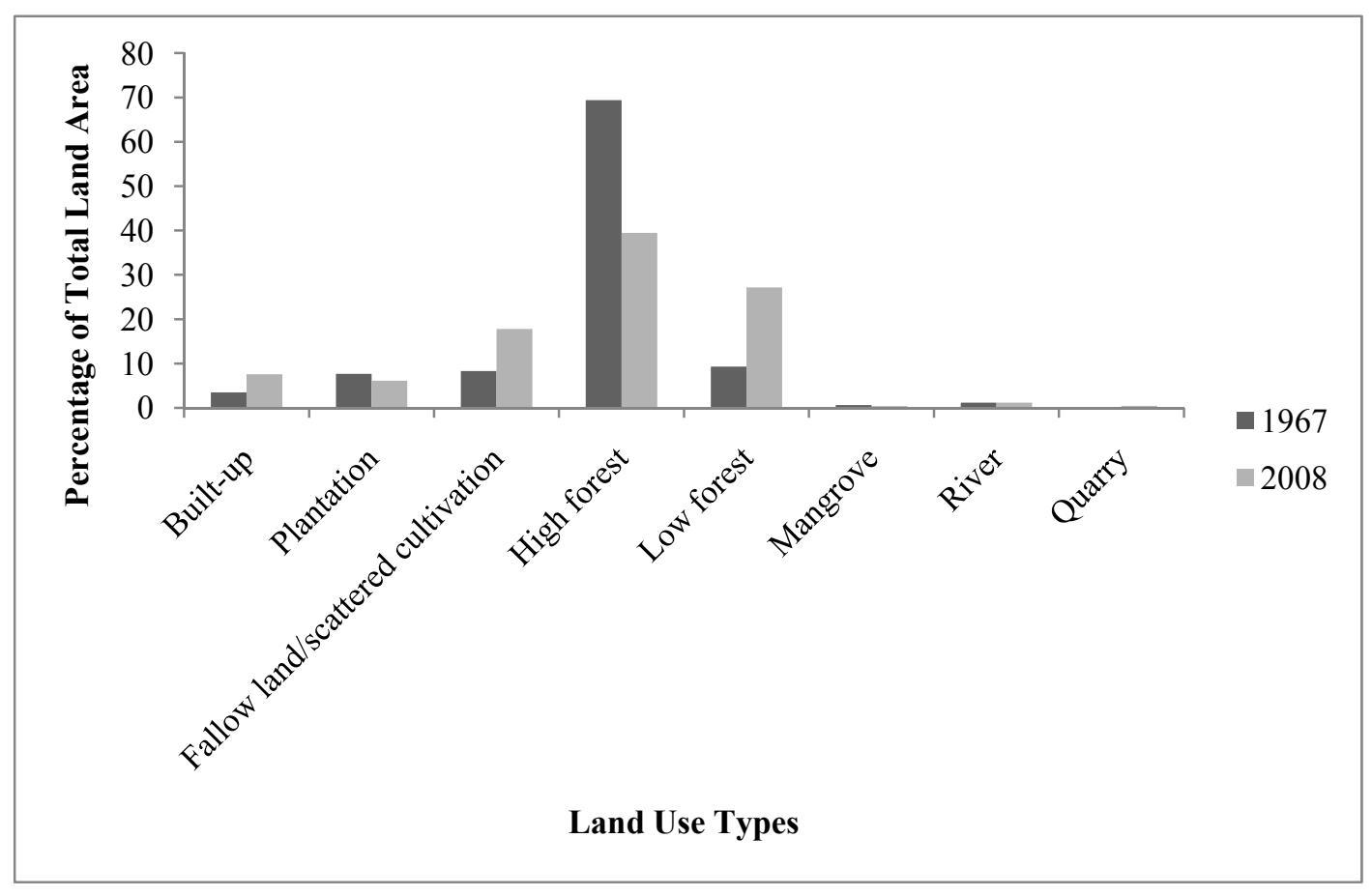

Figure 4. Comparison of land uses between 1967 and 2008 